\title{
Hydrogeologic Investigations in Western Crete by Using Isotopic Analyses and GIS Techniques
}

\author{
Elias Dimitriou*, Paraskevi Tsintza \\ Hellenic Centre for Marine Research, Institute of Marine Biological Resources and Inland Waters, Anavissos, \\ Greece \\ Email: ${ }^{*}$ elias@hcmr.gr
}

Received 22 June 2015; accepted 17 August 2015; published 20 August 2015

Copyright (C) 2015 by authors and Scientific Research Publishing Inc.

This work is licensed under the Creative Commons Attribution International License (CC BY). http://creativecommons.org/licenses/by/4.0/

c) (i) Open Access

\begin{abstract}
Using isotopic techniques to investigate hydrogeologic properties of aquifers and springs is a common approach nowadays that overcomes problems of monitoring classical hydrogeologic parameters such as piezometric levels and groundwater flow velocities. Nevertheless, interpretation of the results and maintenance of long term isotopic monitoring are also difficult and resource consuming tasks. In the present study the isotopic composition of springs and rain water has been examined in various sampling sites of Western Crete in order to identify spring-aquifer interactions and propose appropriate management and restoration measures. The output of this effort illustrated 4 main groups of springs sharing common isotopic characteristics and recharge zones. These potential recharge areas for each group have been delineated by combining the isotopic and geological properties of the entire area with the contribution of GIS techniques.
\end{abstract}

\section{Keywords}

Groundwater, Isotopic Analysis, Oxygen Isotopes, Aquifers, Springs, GIS Technique

\section{Introduction}

During the last decades groundwater systems have been thoroughly investigated to acquire the necessary data for undertaking protection measures against pollution pressures, especially in aquifers destined for public water supply [1]. Nevertheless, in many cases groundwater resources cannot be managed efficiently since the required information is either inadequate or absent which leads to gaps in understanding and designing the appropriate

${ }^{*}$ Corresponding author.

How to cite this paper: Dimitriou, E. and Tsintza, P. (2015) Hydrogeologic Investigations in Western Crete by Using Isotopic Analyses and GIS Techniques. Journal of Water Resource and Protection, 7, 923-937. 
restoration practices.

Isotopic techniques can offer useful information in groundwater investigation efforts [2]-[5] and therefore can facilitate optimum water management decisions [6] [7]. Important hydrogeological information can be provided from stable isotopes such as the groundwater recharge zones, the interrelations between groundwater and surface waters, detection of the water velocity, age and the direction of groundwater flow. Also, basic hydraulic characteristics of aquifers such as transmissivity, porosity and dispersivity can be determined with the contribution of isotopes [2]. This information is valuable for the qualitative and quantitative assessment and management of groundwater resources, especially in aquifers where monitoring efforts of classic hydraulic parameters are limited or missing [8]-[10]. Moreover, environmental isotopes provide also useful information in modeling groundwater systems [11]. According to Koniger [12], isotope studies led to a better understanding of the movement and mixing of the recharge procedures in the Upper Rhine valley aquifer in an area where classic techniques did not provide adequate information about the recharge and origin of groundwater.

Moreover, heavy stable isotopes such as oxygen-18 and deuterium and the radioactive isotopes like carbon-14 and Tritium are involved in groundwater investigations [13]. According to Gibson [14], the isotopes $(1 \mathrm{H}, 2 \mathrm{H}$, $160,180)$ are widely used as tracers in the hydrogeological research. Groundwater studies have been also based on isotopic tracers for identifying interactions between the groundwater bodies and the surrounding springs [14]. Specifically, stable isotopes can give excellent information about the water circulation while the radioactive isotopes can identify the residence time if the groundwater is not contaminated by other water bodies [13].

Although isotopic measurements can give information about the movement of water and recharge in groundwater systems, they can also be used for identifying others useful factors. Oxygen isotopes can be used for the separation of groundwater from the runoff water in surface water bodies [15]. Changes in isotopic composition are caused by chemical interactions related to ground weathering, by evaporation processes and by mixing of water. Isotopic deviations from the precipitation to the groundwater composition show an extended residence time and a mixing of different sources of water [15].

There are many different approaches to estimate recharge zones, including multicriteria analysis of hydrogeological properties, remote sensing, numerical modeling and geochemical investigations [16]-[18]. Nevertheless, there are significant limitations in these approaches, including the intense monitoring efforts required to acquire the necessary information, the time and costs involved as well as the lack of physical interpretation in some of the approaches. On the contrary, several research efforts have been conducted successfully, at a global scale, to delineate the recharge zones of important aquifers by using Oxygen isotopes and hydrogeologic data [18]-[20]. For this purpose, the isotopic signatures of groundwater and rainfall are usually used that reflect the discharge and recharge characteristics of the study catchment [21]. Particularly, Clark and Fritz [15] state that: "the groundwater isotopicsignature reflects a long term average of rain events while the average precipitation signature over a rain event has a discrete concentration that falls within the range of the mean annual concentration”.

The purpose of this study is to identify the relationships between the main groundwater bodies and the springs of Western Crete, estimate the recharge zones of each group of springs while propose management and protection measures for their long term sustainable use.

\section{Methodology}

\subsection{Study Area}

The study area covers the main springs of Western Crete which are used for domestic and irrigation purposes (Figure 1, Table 1). The total water demand in the study area (Prefecture of Chania) is $130 \times 10^{6} \mathrm{~m}^{3}$ on an annual basis and approximately $85 \%$ of this amount is allocated to agriculture and $13 \%$ to domestic uses [22]. The most important springs in terms of discharge and water use are Agyia (domestic supply in the city of Chania), Stylos (large scale bottling factory), and Meskla (Table 1). No regular monitoring of the springs' discharge occurs in the particular area but some indicative measurements from the Water Resources Department of the Regional Authority of Crete illustrate Agya, Almyros, Armenoi and Stylos as the most important springs in terms of discharge (from 63 to $80 \times 10^{6} \mathrm{~m}^{3}$, Table 1). The geological substrate of the study area (Figure 1) comprises calcareous rocks (the White Mountains massif, approx. $42 \%$ of the study area), Flysch formations (western part, approx.: 27\% of the area) and Neogene and Quaternary sediments (lowland, south part, approx.: 31\% of the study area).All the springs under study are located within calcareous areas (limestones) with the exception of the 


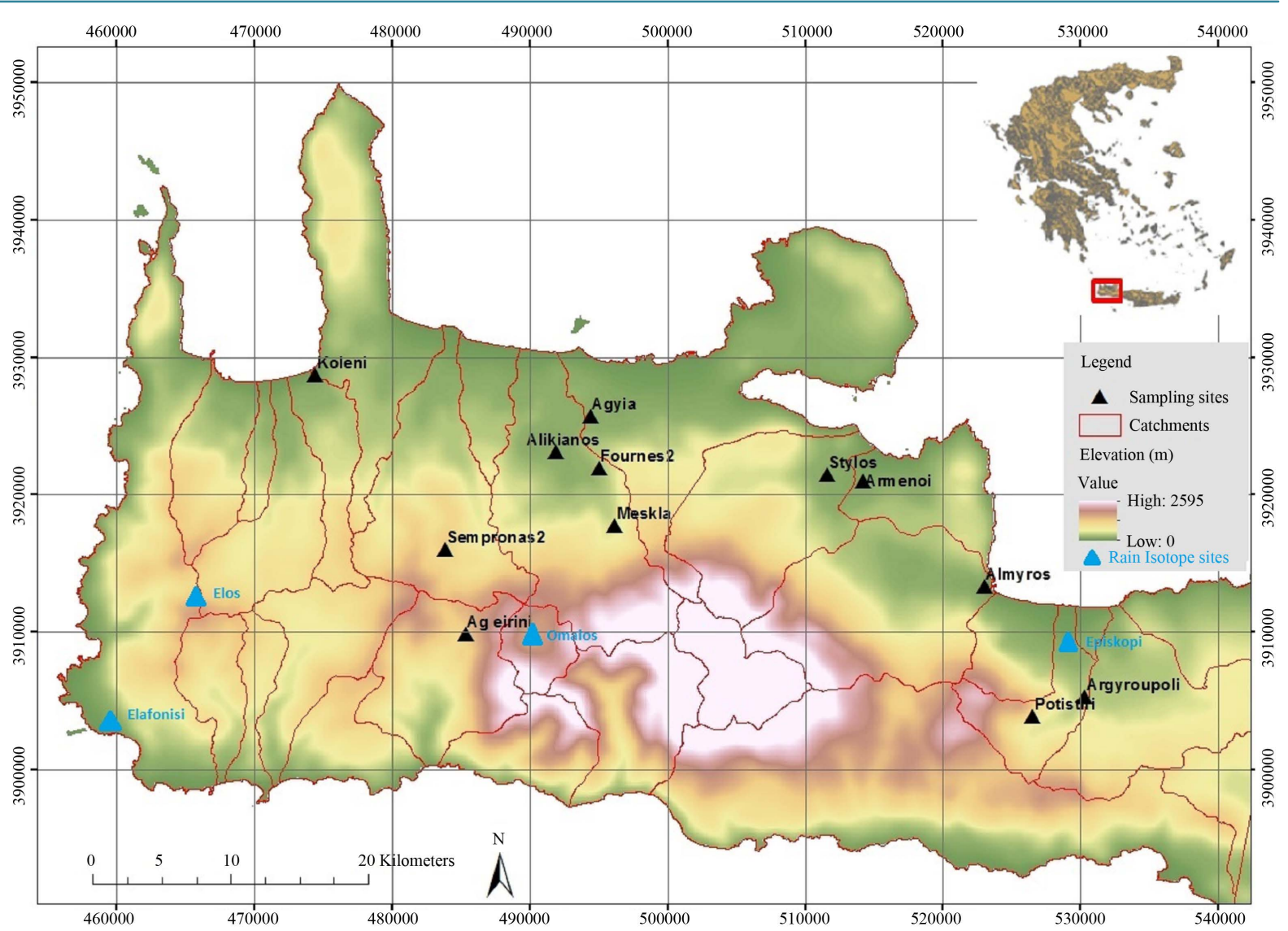

Figure 1. Study area and sampling sites in Western Crete.

Table 1. Location and characteristics of the studied springs.

\begin{tabular}{|c|c|c|c|c|c|}
\hline Springs & X_COORD & Y_COORD & $\begin{array}{l}\text { Aver. Discharge } \\
\qquad\left(\times 10^{6} \mathrm{~m}^{3}\right)\end{array}$ & Water Uses & Importance \\
\hline Ag Eirini & 485,332 & $3,909,862$ & - & Irrigation & Moderate \\
\hline Agyia & 494,421 & $3,925,756$ & 67 & Domestic and Irrigation & Very High \\
\hline Almyros & 523,030 & $3,913,351$ & 63 & & \\
\hline Argyroupoli & 530,343 & $3,905,266$ & 7 & Domestic & High \\
\hline Armenoi & 514,242 & $3,921,008$ & 80 & Domestic and Irrigation & High \\
\hline Fournes 2 & 495,017 & $3,921,918$ & - & Irrigation & Moderate \\
\hline Koleni & 474,398 & $3,928,752$ & 10 & Irrigation & Low \\
\hline Meskla & 496,132 & $3,917,725$ & 31 & Domestic and Irrigation & High \\
\hline Potistiri & 526,555 & $3,903,834$ & - & Irrigation & Low \\
\hline Sempronas 2 & 483,820 & $3,915,980$ & - & Irrigation & Moderate \\
\hline Stulos & 511,591 & $3,921,470$ & 80 & Domestic and Irrigation & Very High \\
\hline
\end{tabular}

lowland springs (Koleni, Stylos and Armenoi) that are found within alluvial deposits, overlaying usually calcareous formations (Figure 2).

\subsection{Sampling Campaign and Analyses}

A series of water samples for isotopic analysis has been collected over the period 2005-2007, from 15 different 


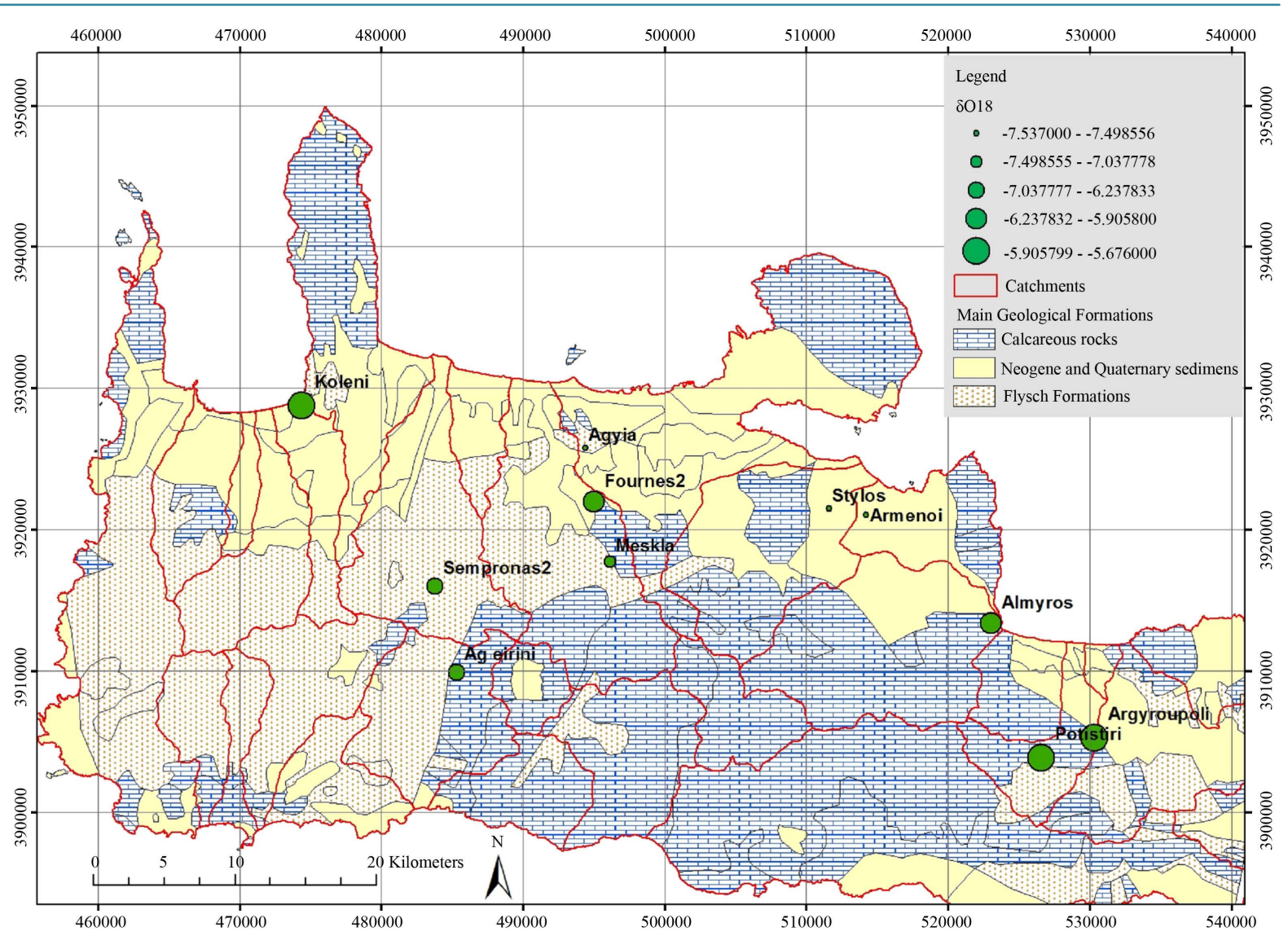

Figure 2. Main geological formations and the average $\delta^{18} \mathrm{O}$ values.

sites (11 springs and 4 rain samples, Figure 2 ) at a seasonal basis (10 sampling campaigns). The samples were collected in plastic bottles of $100 \mathrm{ml}$, following the zero-head air principle and transferred to Demokritus Research Center for isotopic analysis in $\delta^{18} \mathrm{O}$ and Tritium (TU). The equipment used for the analyses of $\delta^{18} \mathrm{O}$ samples is a SIRA Series III sotope Ratio Mass Spectrometer while for the Tritium a Packard-Tricarb LSA Liquid scintillator has been used. The Electrical Conductivity (in $\mu \mathrm{S} / \mathrm{cm}$ ) of the water samples were measured in-situ with a portable Hanna Inc. Instrument. Moreover, a water quality campaign in July 2006, took place in the same sites to identify the qualitative status of the springs and propose specific management measures.

The Oxygen isotopic composition of the water samples were the main focus of this effort, which is defined as delta $(\delta)$ values, expressed in the per mille deviation from the standard isotopic composition known as SMOW (Standard Mean Ocean Water, [15] [23]. The isotopic ratio of ${ }^{18} \mathrm{O} /{ }^{16} \mathrm{O}$ is defined in the following equation:

$$
\delta=\left[\left(R_{\text {sample }}-R_{\text {standard }}\right) /\left(R_{\text {standard }}\right)\right] \times 1000 \%
$$

If the value of $\delta$ is negative then the sample is "depleted" in the light $\mathrm{O}$ isotope (low amount of evaporation and high recharge altitude) while if it is positive the sample is "enriched" in comparison to the standard which means lower recharge altitude and more exposed to the evaporation effect.

All the isotopic values together with the additionally collected data (Tritium, EC, Water quality parameters) underwent a thorough statistical analysis including descriptive statistical estimations, hierarchical clustering and regression analysis. Particularly, the $\delta \mathrm{O}_{18}$ values have been used to identify the groups of springs that have similar behavior and may be affected from the same aquifer. For this process the hierarchical clustering algorithm as well as a box plot analysis in SPSS software has been used. A pair-wise regression analysis followed between the stable isotope concentrations and the physicochemical parameters in order to identify common relationships and trends. Moreover, a correlation matrix has been also estimated to identify links between the major ions concentrations and the stable isotopes levels in all the springs. These results have been combined to interpret the interrelationships between sampling points and identify the common recharge areas. The rainfall samples collected 
from 4 different locations in Western Crete on January 2006 (single rainfall event), covering the local altitude natural variations, were used to estimate the relationship between altitude and $\delta^{18} \mathrm{O}$ values by using the least squared equation approach. The resulted equation has been then used to estimate the recharge altitude of the sampling sites. The average recharge zone altitude for each sampling site was estimated by using the following the following equation:

$$
y=a \cdot x+b
$$

where $y=$ the estimated average recharge zone altitude (m), $a=$ the slope of the least squared regression line connecting rainfall $\delta^{18} \mathrm{O}$ values and altitude, $x=$ the sampling points average $\delta^{18} \mathrm{O}$ value and $b=$ the offset in $\mathrm{y}$ axis of the least squared regression line mentioned above. The particular recharge zone altitude estimations is an approximation of the reality since the available data to justify the accuracy of these estimations are limited but combined with other sources of information such as the geological and topographic substrates can provide the basis for the recharge zones identification.

The clustering exercise used the hierarchical clustering algorithm in R software to identify group of sites with similar behaviour as far as $\delta^{18} \mathrm{O}$ values are concerned. Regression analysis between $\delta^{18} \mathrm{O}$ and TU, Electrical Conductivity and Ca were used to validate the aforementioned groups. Then, the particularly outcome was combined with the recharge zone altitude estimations and the main geological properties of the area to identify common recharge areas and the potential limits of the respective aquifers.

A water quality survey was attempted in all the sites at July 2006 and the acquired water samples were analysed in the hydrochemistry laboratory of the Hellenic Centre for Marine Research. The examined parameters included: $\mathrm{SiO}_{2}, \mathrm{Ca}^{2+}, \mathrm{Mg}^{2+}, \mathrm{Na}^{+}, \mathrm{HCO}_{3}^{-}, \mathrm{SO}_{4}^{2-}$ and $\mathrm{NO}_{3}^{-}$. The correlation matrix of these chemical analyses, including the same dates' $\delta^{18} \mathrm{O}$ and Tritium values has been estimated to depict the potential relationships between them while an assessment of the water quality status followed to reassure the classification of springs in groups based on the $\delta^{18} \mathrm{O}$ values.

The potential interactions of the examined springs became apparent through the aforementioned approach and a qualitative assessment followed in all of the studied aquifers to present specific management and protection measures.

\section{Results}

\section{1. $\delta^{180}$ Fluctuations}

The results indicated that the monitored springs illustrate a large variation in their $\delta^{18} \mathrm{O}$ values both in seasonal and interannual basis (Table 2). Particularly, the highest average $\delta^{18} \mathrm{O}$ value was detected in the Agya spring with the value of $-8.15 \%$ followed by the Armenoi spring $\left(-8.10 \%\right.$ ). The lowest $\delta^{18} \mathrm{O}$ value was observed in the Koleni spring $(-4.81 \%$ ) followed by the spring named Argyroupoli with the value of $-4.83 \%$ (Table 2 ). Furthermore, Argyroupoli and Almyros had a low standard deviation ( 0.46 and 0.47 respectively) indicating that the intrannual fluctuations are limited while Ag. Eirini and Fournes 2 had a high standard deviation $(0.77$ and 0.67 respectively) value showing that the $\delta^{18} \mathrm{O}$ values throughout the year were fluctuating significantly. Also, the skewness was calculated (Table 2) which describes the degree of asymmetry of $\delta^{18} \mathrm{O}$ values' distribution around its mean [24]. The majority of the springs had a positive value of skewness and therefore most of their $\delta^{18} \mathrm{O}$ values were lower than their means. Fournes 2 was the only spring which its skewness was negative showing that most of its values were higher than the mean. Moreover, Ag. Eirini and Meskla (followed by Stylos and Armenoi) that present high StD and Skewness are probably affected more from snowmelt than the other sites. This is because snowmelt in high altitude has very low $\delta^{18} \mathrm{O}$ values while rainfall in moderate and low altitudes present relatively high $\delta^{18} \mathrm{O}$ values, especially in Crete. Thus, the aforementioned sampling sites undergo the impact of extremely low $\delta^{18} \mathrm{O}$ values more frequently than the other sites.

The seasonal fluctuation of $\delta^{18} \mathrm{O}$ values (Figure 2 and Figure 3) indicates that the highest values were observed in October 2006 and July 2006, while the lowest ones in January 2006 and November 2005. The springs such as Koleni, Almyros, Argyroupoli, Meskla, Agiya, followed more closely this particular seasonal pattern than the rest of the sampling sites. Armenoi and Stylos illustrated their highest values in April and November 2006 while their lowest values were the same of the other sites. This behavior could be related to the main water supply mechanism that changes throughout the year. Particularly, for the sampling sites that have recharge zones affected by snowmelt mostly the spring and summer periods are the ones with the highest $\delta^{18} \mathrm{O}$ values (Armenoi 
Table 2. Descriptive statistics for the $\delta^{18} \mathrm{O}$ values in the studied sampling sites.

\begin{tabular}{cccccccccccccccc}
\hline & \multicolumn{1}{c}{$\delta^{18} \mathrm{O}(\%)$} \\
\hline Sites & Max & Min & Median & Mean & Std & Var. & Skew & Max & Min & Median & Mean & Std & Var. & Skew \\
\hline Ag Eirini & -5.19 & -7.34 & -6.7 & -6.56 & 0.77 & 0.49 & 1.31 & 334 & 250 & 262 & 277 & 39 & 1493 & 1.81 \\
Agyia & -6.47 & -8.15 & -7.5 & -7.39 & 0.58 & 0.29 & 0.53 & 350 & 281 & 344 & 332 & 29 & 838 & -2.08 \\
Almyros & -5.05 & -6.71 & -6.14 & -6.06 & 0.47 & 0.2 & 1.11 & 2909 & 2180 & 2586 & 2618.2 & 284 & 80879 & -0.91 \\
Argyroupoli & -4.83 & -6.45 & -5.9 & -5.85 & 0.46 & 0.19 & 1.18 & 459 & 359 & 450 & 432 & 41 & 1712 & -2.09 \\
Armenoi & -6.28 & -8.11 & -7.76 & -7.52 & 0.63 & 0.35 & 1.08 & 292 & 217 & 267.5 & 261 & 35 & 1247 & -0.61 \\
Fournes 2 & -5.55 & -7.27 & -6.19 & -6.24 & 0.67 & 0.37 & -0.52 & 460 & 320 & 383.5 & 386.75 & 58 & 3309 & 0.33 \\
Koleni & -4.81 & -6.38 & -5.8 & -5.76 & 0.45 & 0.18 & 0.93 & 840 & 496 & 610 & 633.4 & 126 & 15826 & 1.29 \\
Meskla & -5.64 & -7.81 & -7.18 & -7.04 & 0.64 & 0.36 & 1.35 & 381 & 267 & 327 & 330.2 & 42 & 1737 & -0.66 \\
Potistiri & -5.17 & -6.39 & -6.09 & -5.91 & 0.48 & 0.19 & 1.01 & 475 & 327 & 424 & 411.8 & 57 & 3196 & -0.77 \\
Sempronas 2 & -5.63 & -7.09 & -6.8 & -6.53 & 0.59 & 0.28 & 1.04 & 320 & 154 & 161 & 199 & 81 & 6542 & 1.97 \\
Stulos & -6.29 & -8.1 & -7.79 & -7.54 & 0.63 & 0.35 & 1.06 & 296 & 215 & 258 & 252.2 & 35 & 1245 & 0.03 \\
\hline
\end{tabular}

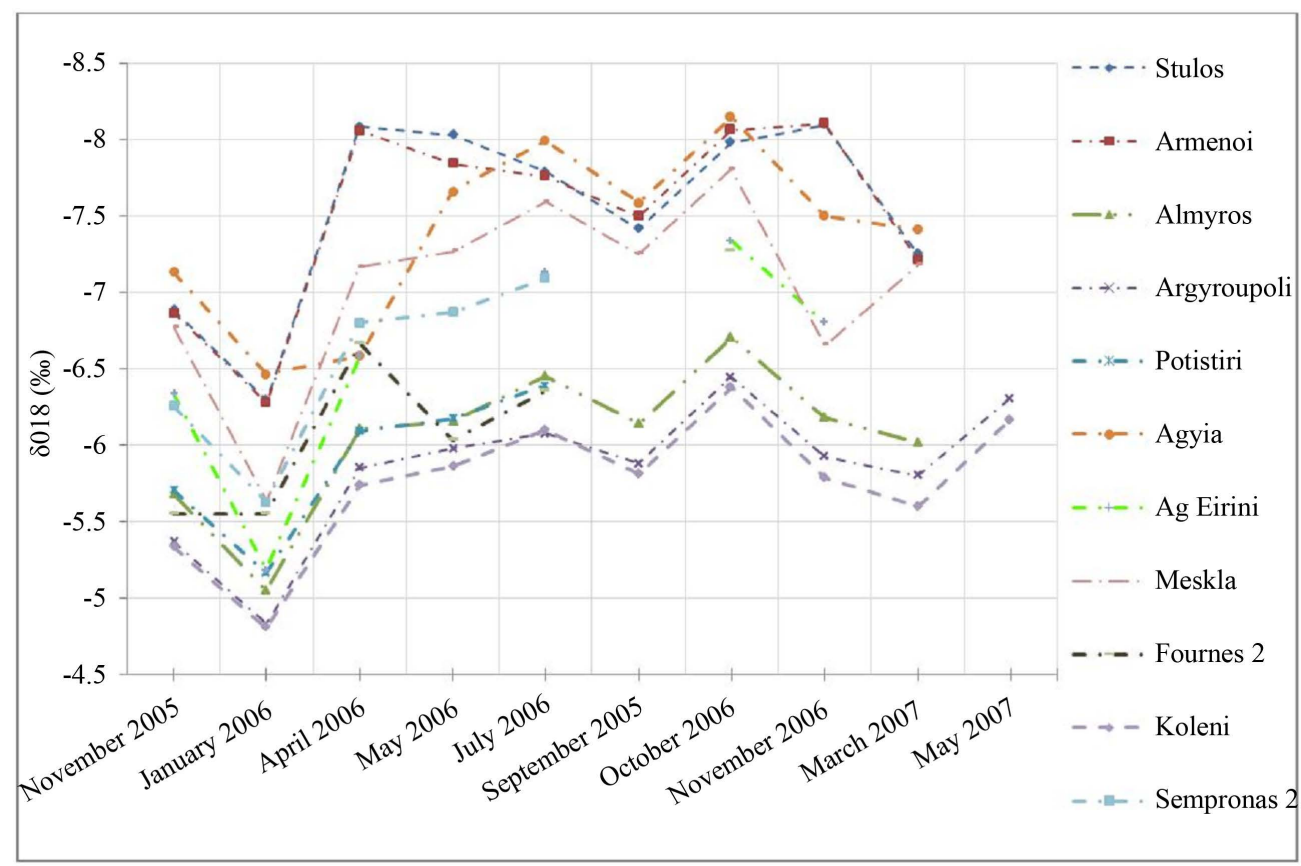

Figure 3. The $\delta^{18} \mathrm{O}$ values fluctuations in the 11 springs from November 2005 to May 2007.

and Stylos) due to the characteristic $\delta^{18} \mathrm{O}$ values of snowmelt and the extended travel time that can fluctuate from 2 - 5 months. The sites that are both affected by snowmelt and rainfall have higher seasonal fluctuations but always in the lower levels of $\delta^{18} \mathrm{O}$ values (Meskla, Agya, Ag. Eirini) while the ones that are located in lower altitudes and are mostly affected by rainfall have significant seasonal fluctuations at a lower $\delta^{18} \mathrm{O}$ level (Almyros, Koleni, Argyroupoli).

The similarity index of the cluster analysis indicated that Stylos and Armenoi are very close not only in absolute values but also in their seasonal and interannual fluctuations. The same stands for Ag. Eirini and Sempronas 2 while Meskla and Fournes 2 illustrate the most dissimilar behavior in relation to the all other sites.

Thus, according to the seasonal fluctuations and the cluster analysis two main group of springs can be observed from the data; the first one includes Agiya, Amenoi, Stylos and Meskla while the second one Koleni, Argyroupoli, Almyros and Potistiri (Figure 4). 


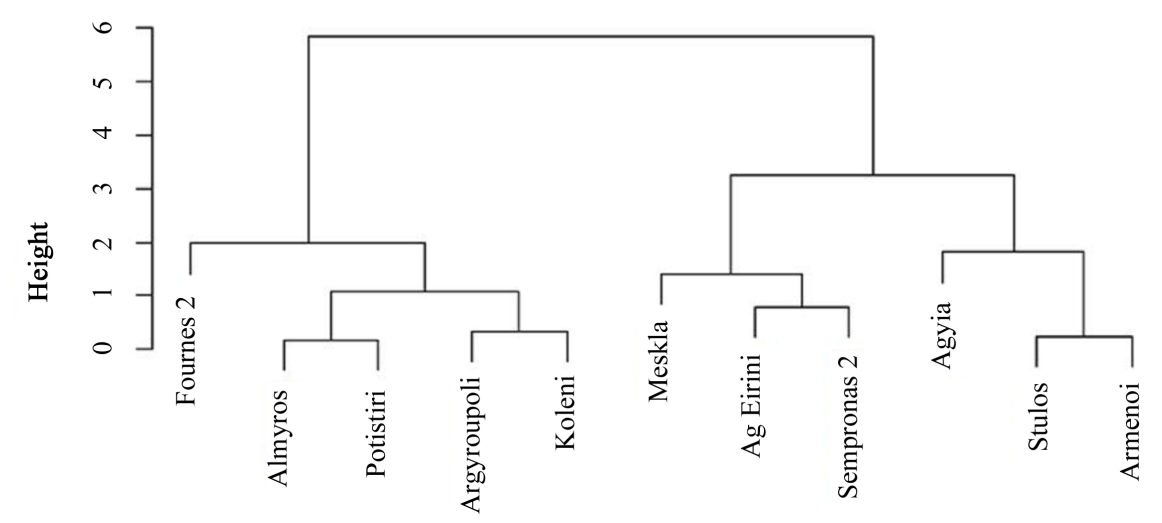

Figure 4. The cluster analysis of the $\delta \mathrm{O}_{18}$ values for the springs.

The Box and Whisker plot of all the data (Figure 5) shows the substantially different behavior of the various sampling sites as far as $\delta^{18} \mathrm{O}$ is concerned. The majority of springs did not have a normal distribution apart from the springs named Ag. Eirini and Fournes 2 which presented a distribution close to normal. The highest median of $\delta \mathrm{O}_{18}$ values appeared in Stulos spring and the lowest one in Koleni (Figure 5). The maximum range of the $\delta^{18} \mathrm{O}$ values was found in Fournes 2 while the minimum one in Almyros. The clustering groups of sampling sites described above are also accredited by the Box and Whisker plot since Stulos and Armenoi have very similar distribution of values while the same stands for Almyros, Argyroupoli and Potistiri, as well as for Agyia and Meskla and to a lesser extend for Ag. Eirini and Sempronas (Figure 5).

\subsection{Correlation between $\delta 180$ and Other Parameters}

The $\delta^{18} \mathrm{O}$ values of the sampling sites have been correlated with other measured parameters such as Electrical Conductivity (EC), Tritium and Ca to identify potential relationships between these parameters and distinguish group of sites with similarities in their behavior.

Regarding EC, Almyros spring had the greatest values, ranging from $2909 \mu \mathrm{S} / \mathrm{cm}$ to $2180 \mu \mathrm{S} / \mathrm{cm}$ which was expected due to its proximity to the sea and the dominant geological substrate that includes limestones with fluctuating amounts of gypsum (Figure 6). The average conductivity in the rest sampling sites fluctuated between $633.40 \mu \mathrm{S} / \mathrm{cm}$ and $252.20 \mu \mathrm{S} / \mathrm{cm}$ which are typical values for karstic groundwater with relatively limited residence time.

The least squared regression between EC and $\delta^{18} \mathrm{O}$ indicates a quite low correlation coefficient (0.364) between the two parameters which is mainly due to Almyros site that appears as an outlier in the analysis. According to their scatterplot (Figure 6), there is a positive linear relationship between conductivity and $\delta^{18} \mathrm{O}$ which groups the sites in a similar way as the previously mentioned analyses.

The Tritium values show a slightly positive linear relationship with the $\delta^{18} \mathrm{O}$ values but again the correlation coefficient is low (0.1531) showing that this relationship is not statistically significant (Figure 7). The greatest range of Tritium values was observed in Fournes 2 with the maximum and minimum ones to be 16.7 TU and 4.2 TU respectively (Figure 8). The average Tritium values of the rest of the springs fluctuated between 5.66 TU and 2.76 TU while Sempronas 2 had the lowest average Tritium value (2.79 TU). In terms of groundwater age, based on the Tritium concentrations, Ag. Eirini and Sempronas have relatively low values which indicates a mixture of recent and old (prior to 1952) water [15] while the rest of the sampling sites have Tritium values from 4 to 10.5 TU which indicates modern water. The regression analysis between Tritium and $\delta^{18} \mathrm{O}$ values (Figure 7) indicates a clear grouping of the samping sites (group 1: Stylos, Armenoi, Agyia, Meskla, group 2: Almyros, Potistiri, Koleni and Argyroupoli, group 3: Ag. Eirini and Sempronas).

The relationship between $\mathrm{Ca}$ and $\delta^{18} \mathrm{O}$ values in the particular sampling sites were weak but reassured some of the aforementioned groups (Figure 9). Almyrosand Koleni springs had the highest Ca values (107 mg/l and 61mg/l respectively) while Sempronas 2 and Ag. Eirini had the lowest ones (20 mg/l and 35 mg/l respectively). Stulos, Armenoi and Agyia presented very similar Ca values while Argyroupoli and Koleni had almost identical 


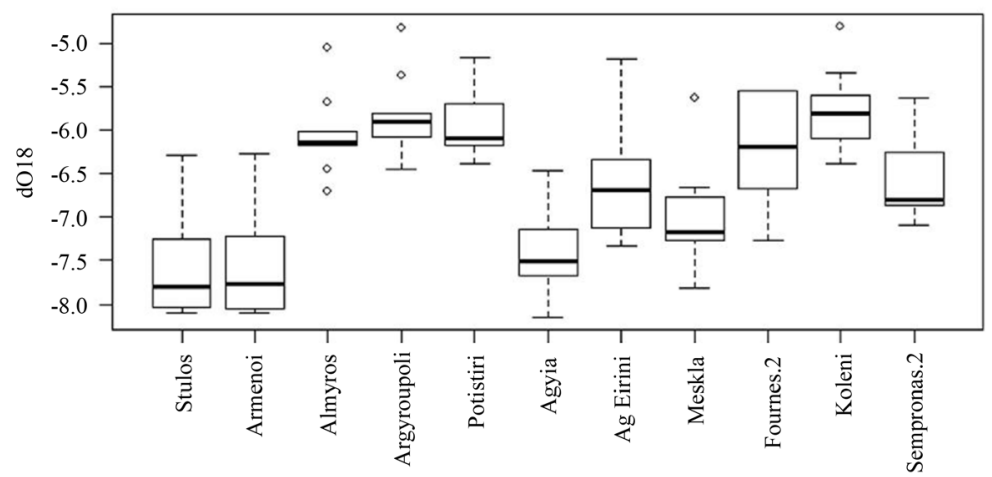

Figure 5. The boxplots of the $\delta \mathrm{O}^{18}$ values in the different springs.

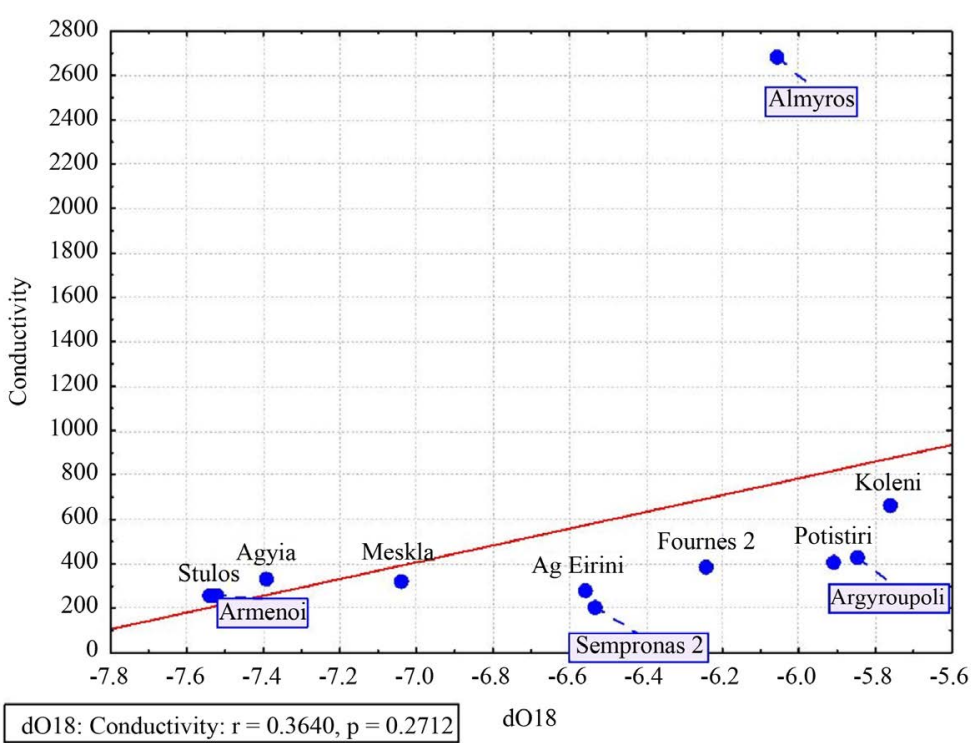

Figure 6. The scatterplot of the conductivity against $\delta \mathrm{O}^{18}$.

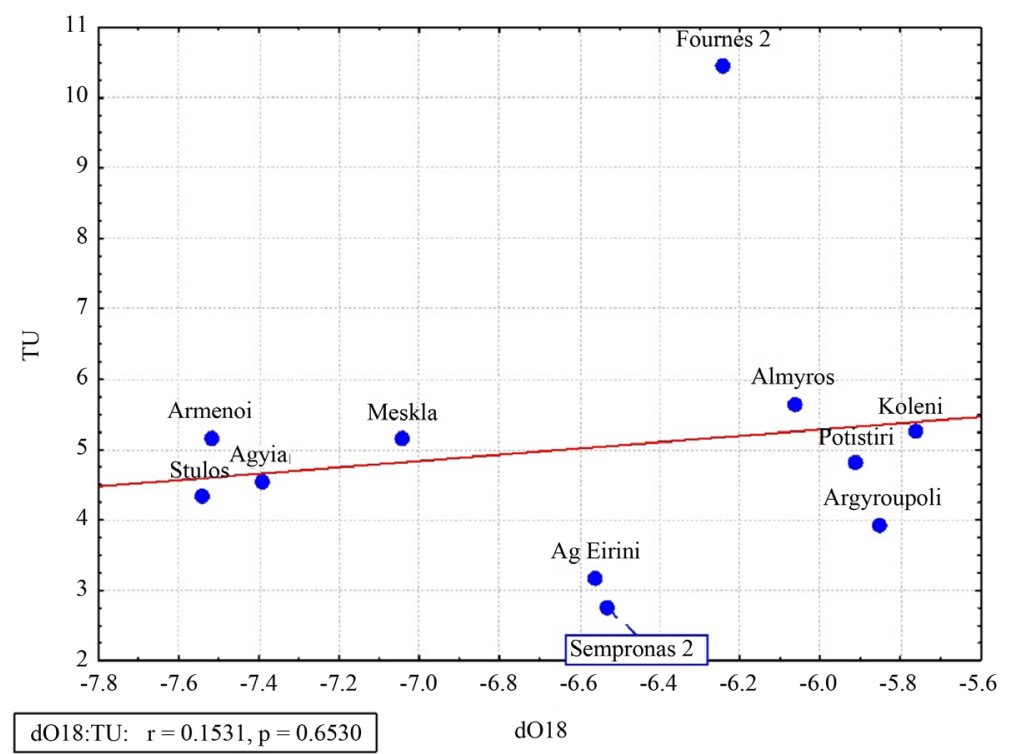

Figure 7. The scatterplot of the Tritium against $\delta \mathrm{O}_{18}$. 


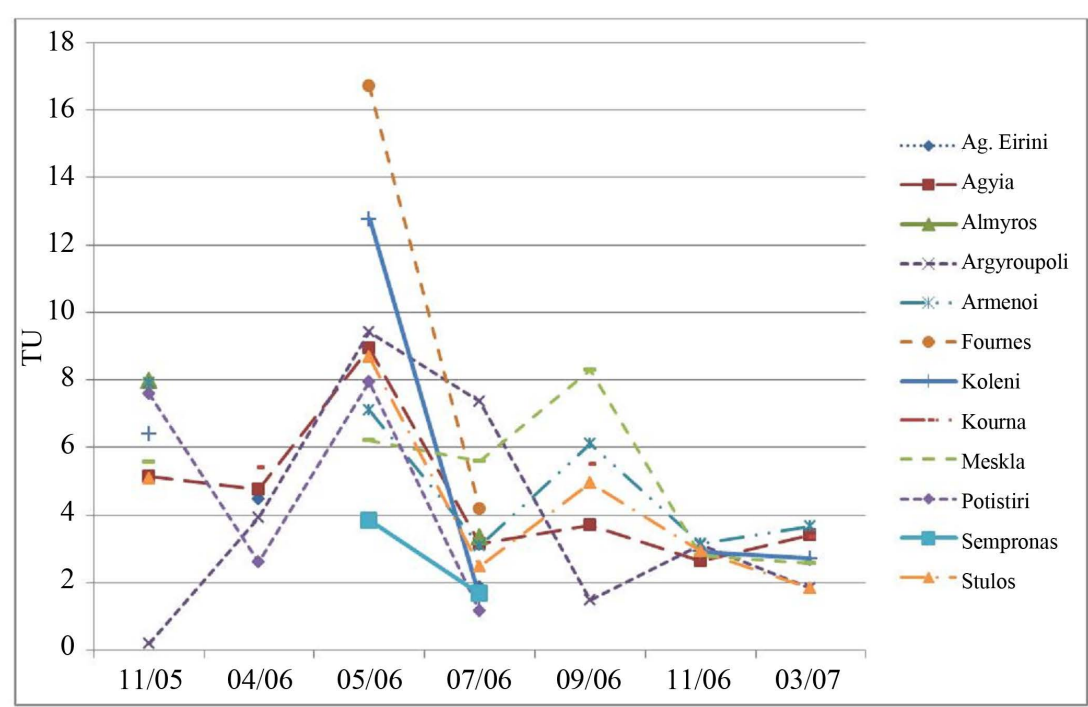

Figure 8. The temporal variations of the Tritium values in the study area.

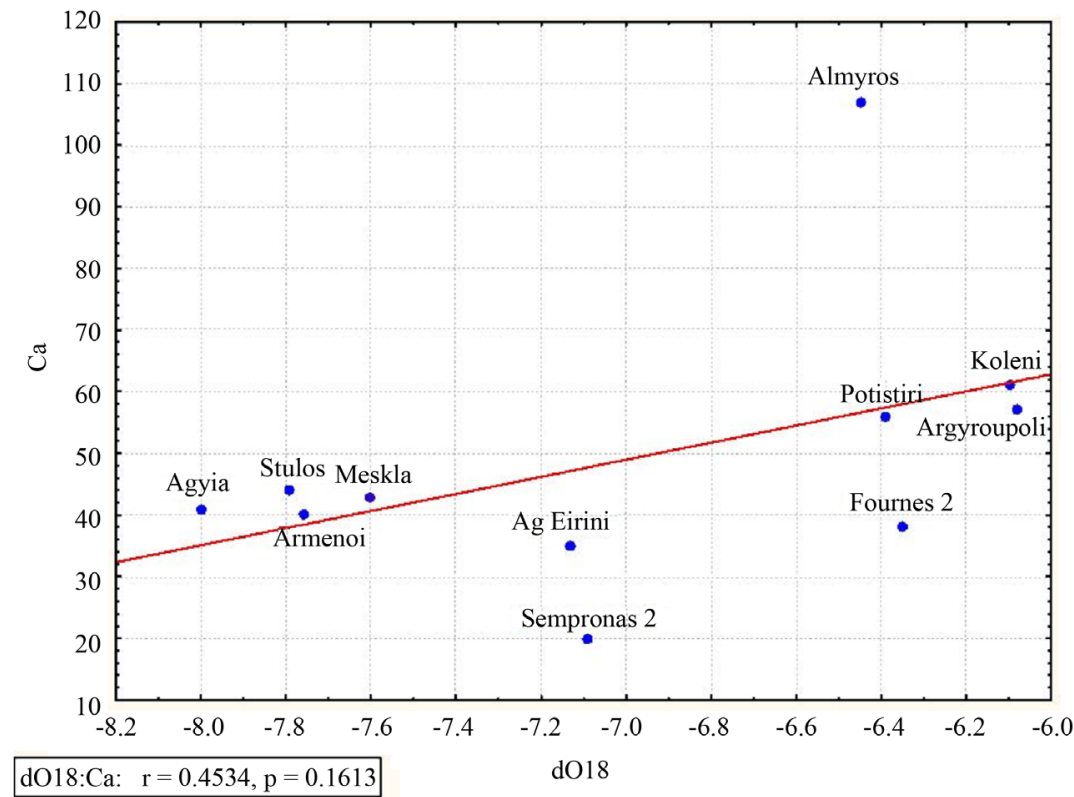

Figure 9. The scatterplot of the Ca against $\delta \mathrm{O}_{18}$.

concentrations (Figure 9). The different concentrations of Ca in the studied springs express the high variation of the geological formations and the groundwater residence times in the particular area. Springs with relatively low Ca concentrations such as Sempronas and Ag. Eirini indicate probably aquifers with limited calcareous content and/or short travel times. Proximity in the sea also affects the Ca concentrations significantly, such as the case of Almyros spring.

\subsection{Recharge Zones}

The rainfall sampling sites and their $\delta^{18} \mathrm{O}$ values have been used to estimate the relationship between $\delta^{18} \mathrm{O}$ and recharge altitude in the study area (Figure 10). The coefficient of determination for the identified relationship was very high (0.84) and therefore the associated regression equation could be used to estimate the potential, average recharge zone altitude for all the sampling sites (Table 3).

Stulos spring had the greatest average recharge altitude $(1040 \mathrm{~m})$ followed by Armenoi and Agiya springs 


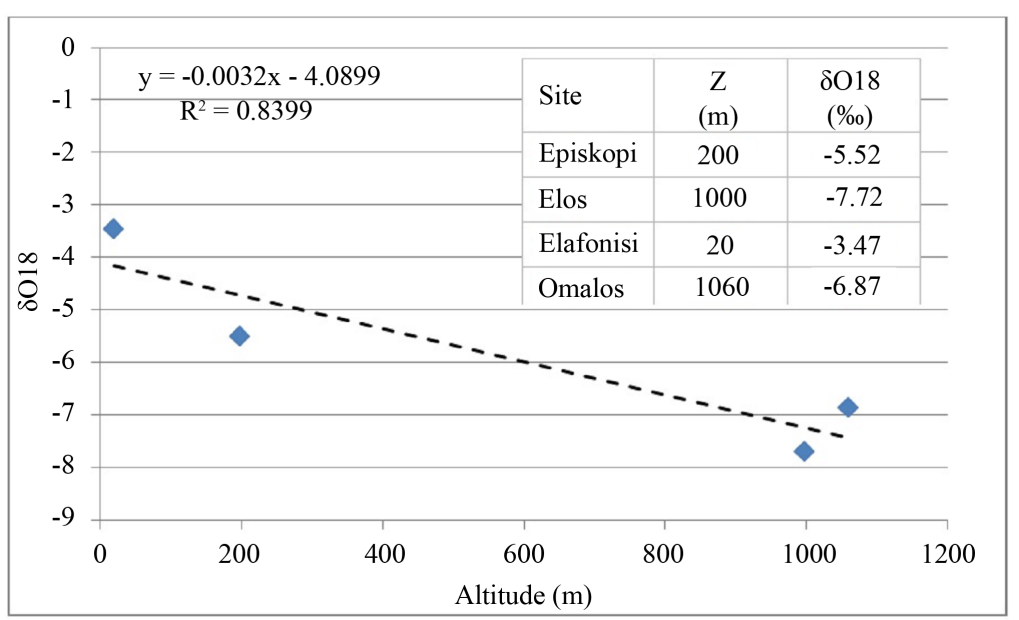

Figure 10. Regression analysis between $\delta^{18} \mathrm{O}$ and recharge altitude.

Table 3. Estimated recharge altitude for all the sampling sites and dates.

\begin{tabular}{ccccccccc}
\hline & Altitude & \multicolumn{7}{c}{ Est. Recharge Altitude $(\mathrm{m})$} \\
Names & $\mathrm{m}$ & $11 / 05$ & $01 / 06$ & $04 / 06$ & $05 / 06$ & $07 / 06$ & Average & Range \\
Ag Eirini & 631 & 700 & 340 & 780 & & 950 & 690 & 610 \\
Agyia & 83 & 950 & 740 & 1090 & 1120 & 1220 & 1020 & 480 \\
Almyros & 56 & 500 & 300 & 630 & 650 & 740 & 560 & 440 \\
Argyroupoli & 79 & 400 & 230 & 560 & 590 & 620 & 480 & 390 \\
Armenoi & 46 & 870 & 680 & 1240 & 1170 & 1150 & 1020 & 560 \\
Fournes 2 & 164 & & 460 & 810 & 610 & 710 & 650 & 350 \\
Koleni & 44 & 390 & 220 & 520 & 550 & 630 & 460 & 410 \\
Meskla & 267 & 840 & 480 & 960 & 990 & 1100 & 870 & 620 \\
Potistiri & 429 & 500 & 340 & 630 & 650 & 720 & 570 & 380 \\
Sempronas 2 & 620 & 680 & 480 & 850 & 870 & 940 & 760 & 460 \\
Stulos & 77 & 870 & 690 & 1250 & 1230 & 1160 & 1040 & 560 \\
\hline
\end{tabular}

(1020 m). Koleni and Argyroupoli had the lowest average recharge altitude (460 and $480 \mathrm{~m}$ respectively), followed by Almyros (560 m) and Potistiri $(570 \mathrm{~m}$, Table 3). The potential seasonal fluctuations in the recharge zone altitudes of each site indicate that Ag. Eirini and Meskla have the highest values (range of 610 and $620 \mathrm{~m}$ respectively), while Fournes and Potistiri have the lower variations (350 and $380 \mathrm{~m}$ respectively, Table 3).

The scatterplot of recharge altitude against $\delta^{18} \mathrm{O}$ values (Figure 11), illustrates again the strong negative linear relationship between these parameters while re-validates the grouping effects mentioned before in the particular study.

By combining the sampling sites clustering and topographic information together with their recharge zones altitude and the dominant geological conditions, an effort has been made to delineate the recharge zone boundaries for each site as well as the common aquifers shared by each group of sites (Figure 12). These recharge zones present only the potential areas of water supply for each group of springs, based on the fluctuations of the average recharge altitudes for each sample and the dominant geological substrate. Nevertheless, more work needs to be done to validate and possibly amend these areas by using more isotopic data and reference values to optimize and/or accredit the relationship between recharge altitude and isotopic values.

\section{Water Quality Results}

The main pollution pressures in the study area are agrochemicals and untreated urban waste from villages and 


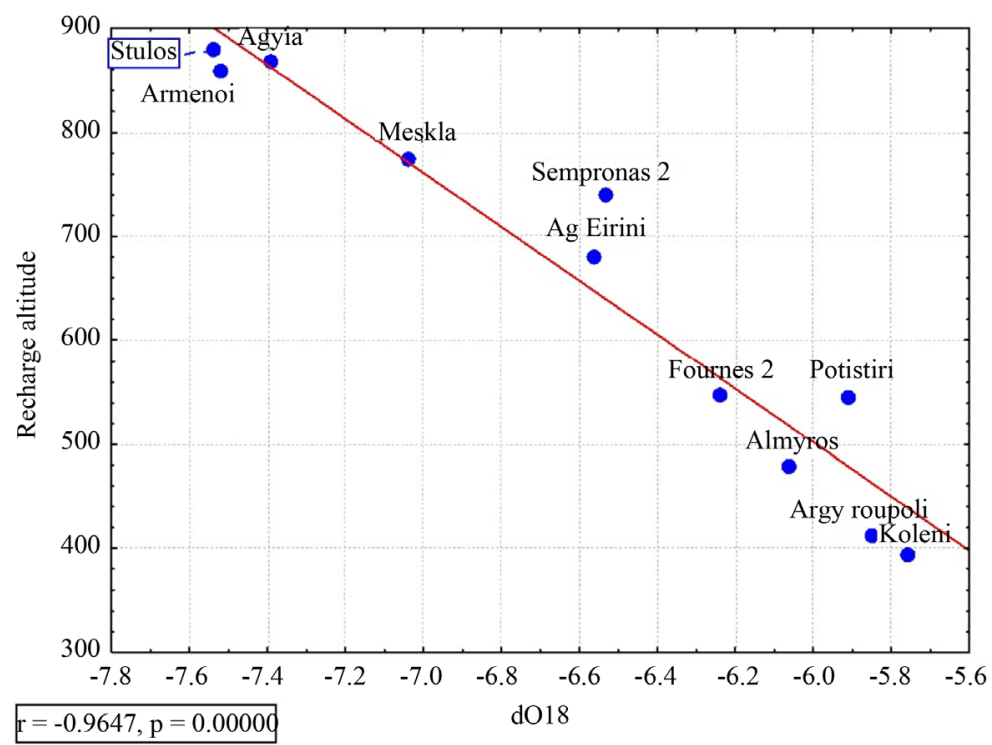

Figure 11. The scatterplot of the recharge altitude against $\delta^{18} \mathrm{O}$.

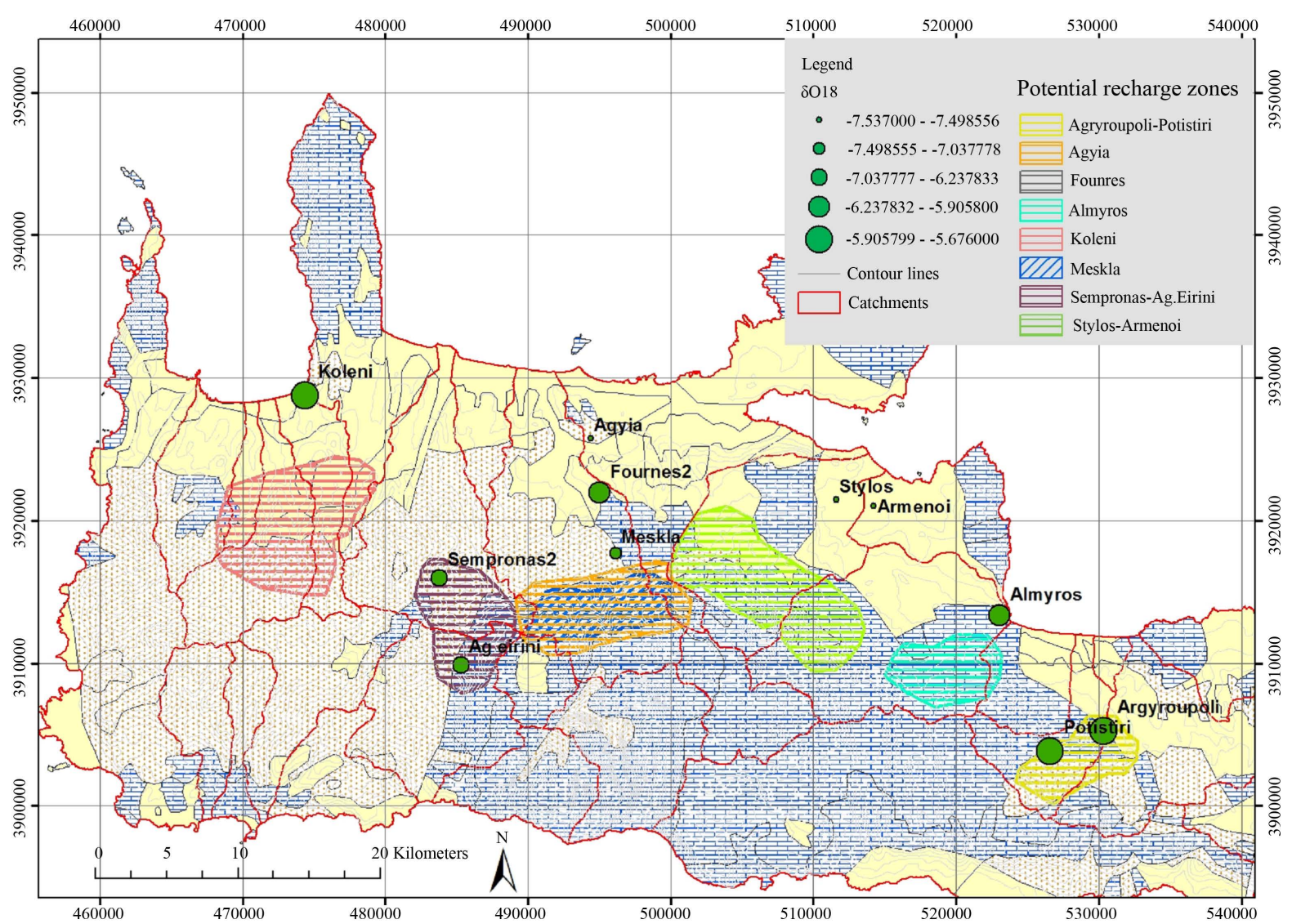

Figure 12. Potential recharge zones of the main springs of Western Crete.

touristic infrastructure. Therefore, if the pollution pressures are exceeding the carrying capacity of the hydrogeological systems in terms of natural attenuation, elevated levels of $\mathrm{NO}_{3}, \mathrm{SO}_{4}$ and $\mathrm{Na}$ are expected. However, the water quality analyses (Table 4) indicates that there is no evidence of significant pollution impacts in the particular springs with the exception of Potistiri site where $\mathrm{NO}_{3}$ reaches $15 \mathrm{mg} / \mathrm{l}$. In the rest of the study sites the 
$\mathrm{NO}_{3}$ concentrations were less than $4 \mathrm{mg} / \mathrm{l}$ and $\mathrm{SO}_{4}$ levels were below $35 \mathrm{mg} / \mathrm{l}$ with the exception of Almyros which is influenced by the sea (brackish waters).

The correlation matrix (Table 5) indicates that $\mathrm{Ca}, \mathrm{Na}, \mathrm{Mg}, \mathrm{SO}_{4}$ and Conductivity have very high correlation coefficients which is due to their common origin in this area (either from rocks weathering or sea intrusion/ spray effect) while the rest of the parameters do not illustrate significant relationships amongst them. Intermediate correlation coefficient have been estimated between $\mathrm{HCO}_{3}$ and $\delta^{18} \mathrm{O}(0.422)$ as well as between $\mathrm{NO}_{3}$ and $\delta^{18} \mathrm{O}\left(0.395\right.$, Table 5). This indicates that in many cases, the more positive the $\delta^{18} \mathrm{O}$, the highest the $\mathrm{HCO}_{3}$ and $\mathrm{NO}_{3}$ values in groundwater. This is an expected trend that has to do with the groundwater residence times and the density of the pollution sources that is higher in the lowlands (where most of the agricultural land and touristic areas are located).

The variations in the water quality parameters accredit the grouping of sites occurred based on the $\delta^{18} \mathrm{O}$ values (Table 4). Armenoi and Stylos illustrate common Ca (40 and $44 \mathrm{mg} / \mathrm{l}$ respectively) and $\mathrm{Mg}$ (6.7 and $6.8 \mathrm{mg} / \mathrm{l}$ respectively) values and the same stands for Argyroupoli and Potistiri (Ca: 57 and $56 \mathrm{mg} / \mathrm{l}$ respectively while Mg: 10 and $9.8 \mathrm{mg} / \mathrm{l})$. Almyros is clearly influenced by the sea (Na: $778 \mathrm{mg} / \mathrm{l}$ and $\mathrm{SO}_{4}: 313 \mathrm{mg} / \mathrm{l}$ ) due to its close proximity to the shore and therefore the water quality parameters cannot provide appropriate information to justify its prior grouping based on the $\delta^{18} \mathrm{O}$ values. Moreover, Ag. Eirini and Sempronas 2 present very similar $\mathrm{Mg}$ ( 5 and $3 \mathrm{mg} / \mathrm{l}$ respectively) and $\mathrm{SiO}_{2}$ (5.66 and $5.6 \mathrm{mg} / \mathrm{l}$ respectively) levels but have some differences in

Table 4. Water quality analysis and isotopic levels for the study sites.

\begin{tabular}{cccccccccccc}
\hline & $\mathrm{SiO}_{2}$ & $\mathrm{Ca}$ & $\mathrm{Mg}$ & $\mathrm{Na}$ & $\mathrm{HCO}_{3}$ & $\mathrm{SO}_{4}$ & $\mathrm{NO}_{3}$ & $\delta \mathrm{O}_{18}$ & $\mathrm{TU}$ & $\mathrm{Cond}$ \\
\hline Sites & $\mathrm{mg} / \mathrm{l}$ & $\mathrm{mg} / \mathrm{l}$ & $\mathrm{mg} / \mathrm{l}$ & $\mathrm{mg} / \mathrm{l}$ & $\mathrm{meq} / \mathrm{l}$ & $\mathrm{mg} / \mathrm{l}$ & $\mathrm{mg} / \mathrm{l}$ & $\%$ & $\mathrm{TU}$ & $\mu \mathrm{S} / \mathrm{cm}$ \\
\hline Ag Eirini & 5.66 & 35 & 5 & 12 & 2.196 & 12.6 & 2 & -7.13 & 1.88 & 267 \\
Agyia & 4.29 & 41 & 11 & 7.9 & 2.899 & 12.1 & 1.8 & -8 & 3.15 & 344 \\
Almyros & 4.52 & 107 & 80 & 778 & 2.782 & 313 & 3.8 & -6.45 & 3.34 & 2830 \\
Argyroupoli & 5.69 & 57 & 10 & 18 & 3.556 & 13.4 & 2.8 & -6.08 & 7.35 & 440 \\
Armenoi & 3.26 & 40 & 6.7 & 7.5 & 2.895 & 3.8 & 2.1 & -7.76 & 3.09 & 287 \\
Fournes 2 & 7.31 & 38 & 4.9 & 20 & 2.25 & 22.8 & 2.7 & -6.35 & 4.2 & 377 \\
Koleni & 7.43 & 61 & 22 & 28 & 3.798 & 34.7 & 3.8 & -6.1 & 1.5 & 619 \\
Meskla & 4.51 & 43 & 8.9 & 11.00 & 2.636 & 5.1 & 1.9 & -7.6 & 5.59 & 327 \\
Potistiri & 3.49 & 56 & 9.8 & 14 & 3.101 & 11 & 14.7 & -6.39 & 1.16 & 424 \\
Sempronas 2 & 5.6 & 20 & 3 & 11.00 & 1.189 & 12.8 & 1.8 & -7.09 & 1.67 & 2.5 \\
Stulos & 3.88 & 44 & 6.8 & 8.20 & 2.677 & 4 & 2.6 & -7.79 & 296 \\
\hline
\end{tabular}

Table 5. Correlation matrix for water quality and isotopic parameters for the study sites.

\begin{tabular}{ccccccccccc}
\hline & $\mathrm{SiO}_{2}$ & $\mathrm{Ca}$ & $\mathrm{Mg}$ & $\mathrm{Na}$ & $\mathrm{HCO}_{3}$ & $\mathrm{SO}_{4}$ & $\mathrm{NO}_{3}$ & $\mathrm{dO} 18$ & $\mathrm{TU}$ & $\mathrm{Cond}$ \\
\hline $\mathrm{SiO}_{2}$ & 1.000 & -0.031 & -0.034 & -0.092 & 0.120 & -0.029 & -0.275 & 0.612 & 0.118 & -0.039 \\
$\mathrm{Ca}$ & -0.031 & 1.000 & $\mathbf{0 . 9 5 6}$ & $\mathbf{0 . 9 1 5}$ & 0.320 & $\mathbf{0 . 9 2 3}$ & 0.207 & 0.479 & -0.003 & $\mathbf{0 . 9 4 8}$ \\
$\mathrm{Mg}$ & -0.034 & $\mathbf{0 . 9 5 6}$ & 1.000 & $\mathbf{0 . 9 8 0}$ & 0.112 & $\mathbf{0 . 9 8 6}$ & 0.026 & 0.310 & -0.051 & $\mathbf{0 . 9 9 3}$ \\
$\mathrm{Na}$ & -0.092 & $\mathbf{0 . 9 1 5}$ & $\mathbf{0 . 9 8 0}$ & 1.000 & -0.054 & $\mathbf{0 . 9 9 7}$ & 0.002 & 0.258 & -0.007 & $\mathbf{0 . 9 9 4}$ \\
$\mathrm{HCO}_{3}$ & 0.120 & 0.320 & 0.112 & -0.054 & 1.000 & -0.027 & 0.242 & 0.422 & 0.070 & 0.039 \\
$\mathrm{SO}_{4}$ & -0.029 & $\mathbf{0 . 9 2 3}$ & $\mathbf{0 . 9 8 6}$ & $\mathbf{0 . 9 9 7}$ & -0.027 & 1.000 & 0.001 & 0.302 & -0.027 & $\mathbf{0 . 9 9 7}$ \\
$\mathrm{NO}_{3}$ & -0.275 & 0.207 & 0.026 & 0.002 & 0.242 & 0.001 & 1.000 & 0.395 & -0.426 & 0.037 \\
$\mathrm{dO}_{18}$ & 0.612 & 0.479 & 0.310 & 0.258 & 0.422 & 0.302 & 0.395 & 1.000 & 0.086 & 0.328 \\
$\mathrm{TU}$ & 0.118 & -0.003 & -0.051 & -0.007 & 0.070 & -0.027 & -0.426 & 0.086 & 1.000 & -0.018 \\
$\mathrm{Cond}$ & -0.039 & $\mathbf{0 . 9 4 8}$ & $\mathbf{0 . 9 9 3}$ & $\mathbf{0 . 9 9 4}$ & 0.039 & $\mathbf{0 . 9 9 7}$ & 0.037 & 0.328 & -0.018 & 1.000 \\
\hline
\end{tabular}


the Ca concentrations (35 and $20 \mathrm{mg} / \mathrm{l}$ respectively, Table 4). This could be due to the slightly different travel time of the water discharges in these 2 springs.

\section{Discussion and Conclusions}

The use of stable isotopes as tracers for the study of groundwater movement and interactions between different aquifers has both advantages and disadvantages. The most important advantage is that the isotopes concentration in groundwater cannot be influenced by the potential reactions between rocks and the groundwater, under normal temperatures. There is also a relationship between the isotopes of oxygen and altitude, latitude and season which allows for the identification of potential recharge zones for springs. Areas with higher latitude are characterized by more negative $\delta^{18} \mathrm{O}$ values than the sites with lower latitude [15].

Nevertheless, the use of isotopes for the study of hydrogeological groundwater characteristics has also disadvantages. The expensive cost of the isotopic analyses is a reason for the limited use of them in the groundwater research. A great number of samples must be collected and a significant number of isotopic analyses are required for a complete study of a groundwater system [25].

Particularly, the present isotope study in Western Crete led to a better understanding of the movement and mixing procedures of the different aquifers and their relationships with the main springs of the area. Springs that are fed from common recharge zones have been identified and thus areas of special concern for groundwater management and restoration have been illustrated. Based on the potential recharge zones altitude, the examined springs have been classified in 4 different groups:

$1^{\text {st }}$ group: Stylos, Armenoi, Agyia, Meskla-recharge alt.: 700 - $1300 \mathrm{~m}$ (Meskla presents a bit lower rescharge altitude (500 - $1100 \mathrm{~m})$.

$2^{\text {nd }}$ group: Almyros, Potistiri, Argyroupoli,-recharge alt.: $250 \mathrm{~m}-750 \mathrm{~m}$ (Argyroupoli has a bit lower value in recharge alt. and its UT is very low which means mixing with relatively old groundwater)

$3^{\text {rd }}$ group: Ag. Eirini, Sempronas 2-recharge alt. $\sim 400-950 \mathrm{~m}$

$4^{\text {th }}$ group: Koleni has probably a local recharge area which agrees with the clastic sediments found south of the spring.

The western part of Lefka Ori mountain aquifer (karstic) is discharged through Ag. Eirini, Sempronas, Meskla, Agyia (this spring is probably recharged by the central limestone formation of Lefka Ori which is in higher altitude than the surrounding limestone and dolomitic formations). Stylos and Armenoi discharge the central part of Lefka Ori (limestones and dolomites) while Almyros, Argyroupoli and Potistiri discharge the eastern part of the aforementioned mountain which has relatively lower altitudes (limestone and dolomitic formations). Based on the aforementioned clustering of the studied springs, the fluctuations in the altitude of the potential recharge zones and the dominant hydrogeological conditions of the study area, the potential boundaries of the springs' aquifers have been determined. Particularly, Potistiri and Argyroupoli seem to share a common aquifer while Almyros has its own local recharge zone in the eastern part of the studied area, partially affected by the seawater. Ag. Eirini and Sempronas have also a common aquifer in the center of the study area while Meskla and Agyia partially share a high altitude aquifer in the northern part of the White Mountains. Stylos and Armenoi have also a quite extensive common aquifer in the northeast part of the White Mountains while Koleni and Fournes seem to have smaller, lower altitude and local recharge zones.

The water quality data available accredited the initial grouping of springs based on $\delta^{18} \mathrm{O}$ values and indicated significant variations in the pollution pressures of the studied springs. Potistiri $\mathrm{NO}_{3}$ values indicate the existence of substantial pollution pressures, possibly from agricultural activities, at a local level while the rest of the sites have quite low $\mathrm{NO}_{3}$ levels (less than $4 \mathrm{mg} / \mathrm{l}$ ). The springs with the highest recharge altitude (Armenoi, Stylos and Meskla) illustrate the lowest $\mathrm{SO}_{4}$ values (4 to $5 \mathrm{mg} / \mathrm{l}$ ) while there is a general trend for $\mathrm{SO}_{4}$ to increase as recharge altitude decreases.

Therefore, the springs that have large recharge zones in the higher altitudes and thus higher discharges and good quality waters (Stylos, Armenoi, Meskla, Agyia) should be intensively protected. This could be achieved by avoiding the installation of hazardous activities in the particular significant recharge zones and by imposing specific restrictions in the amount of water abstractions in these areas. The area covering the Potistiri recharge zone should be examined in detail for pollution pressures and immediate restoration measures should be initiated since the current levels of $\mathrm{NO}_{3}$ are significantly elevated and alarming. Nevertheless, further investigations should be done to calibrate and validate the estimated recharge zones of the main springs in the broader area of 
Chania. The sampling campaign should include more seasons and many more rainfall isotopic analyses in order to accredit the relationship between the recharge altitude and the $\delta^{18} \mathrm{O}$ values of the springs. However, the present approach in the particular study area provided important information for the main aquifers' and springs' properties which can be used for the better management and protection of these, important for humans and the environment aquifers.

\section{Acknowledgements}

Special gratitude to Dr. Nikolaos Zouridakis, the responsible researcher of the isotopic hydrology laboratory of the Demokritos Research Center where most of the isotopic analyses took place.

\section{References}

[1] Foster, S., Hirata, R., Gomes, D., D’elia, M. and Paris, M. (2002) Groundwater Quality Protection: A Guide for Water Utilities, Municipal Authorities, and Environment Agencies. World Bank, Washington DC. http://dx.doi.org/10.1596/0-8213-4951-1

[2] Aggarwal, P.K., Froehlich, K. and Kulkarni, K.M. (2007) Environmental Isotopes in Groundwater Studies. In: Silveira, L. and Usunoff, E.J., Eds., Groundwater-Encyclopedia of Live Support Systems, EOLSS Publishers/UNESCO, Paris, 69-92.

[3] Trembaczowski, A. and Halas, S. (1993) Sulphur and Oxygen Isotopes in Sulphates in Natural Waters: (1) Surface Waters of Relatively Unpolluted Terrains. Isotopes in Environmental and Health Studies, 28, 189-213.

[4] Halder, J., Pralong, C., Bonvin, F., Lambiel, F. and Vennemann, W.T. (2014) Application of $\delta^{18} \mathrm{O}, \delta^{13} \mathrm{C}_{\mathrm{DIC}}$, and Major Ions to Evaluate Micropollutant Sources in the Bay of Vidy, Lake Geneva. Isotopes in Environmental and Health Studies, 1-18. http://dx.doi.org/10.1080/10256016.2014.971786

[5] Murillo, R.S., Brooks, E., Elliot, J.W. and Bolla, J. (2015) Isotope Hydrology and Baseflow Geochemistry in Natural and Human-Altered Watersheds in the Inland Pacific Northwest, USA. Isotopes in Environmental and Health Studies, 51, 231-254. http://dx.doi.org/10.1080/10256016.2015.1008468

[6] Dunning, C. (2010) Water Availability to Be Enhanced through Focus on National Water Resources Assessments. International Atomic Energy Agency, Isotope Hydrology Section, Vienna (Austria). http://www.iaea.org/inis/collection/NCLCollectionStore/_Public/42/018/42018869.pdf

[7] Dimitriou, E. and Zacharias, I. (2006) Groundwater Vulnerability and Risk Mapping in a Geologically Complex Area by Using Stable Isotopes, Remote Sensing and GIS Techniques. Environmental Geology, 51, 309-323. http://dx.doi.org/10.1007/s00254-006-0328-8

[8] Hussain, N., Church, T.M. and Kim, G. (1999) Use of 222-Rn and 226-Ra to Trace Groundwater Discharge into the Chesapeake Bay. Marine Chemistry, 65, 127-134. http://dx.doi.org/10.1016/S0304-4203(99)00015-8

[9] Diazconti Carreon, C., Nelson, S., Mayo, A., Tingey, D. and Maren, S. (2003) A Mixed Groundwater System at Midway, UT: Discriminating Superimposed Local and Regional Discharge. Journal of Hydrology, 273, 119-138. http://dx.doi.org/10.1016/S0022-1694(02)00359-1

[10] Jones, I. and Banner, J. (2003) Estimating Recharge Thresholds in Tropical Karst Island Aquifers: Barbados, Puerto Ricoand Guam. Journal of Hydrology, 278, 131-143.

[11] Kendall, C. and Mcdonnell, J.J. (1999) Isotope Tracers in Catchment Hydrology. Elsevier, Amsterdam, 204.

[12] Königer, P., Uhlenbrook, S., Leibundgut, C., Jaeger, L. and Mayer, H. (2001) Isotope Hydrological Investigation on Groundwater Origin in the Flood Plain of the Upper Rhine Valley. In: Seiler, and Wohnlich, Ed., New Approaches Characterizing Groundwater Flow, Swets Zeitlinger, Lisse, 363-366.

[13] Terwey, J.L. (1984) Isotopes in Groundwater Hydrology. Proceedings of the Harare Symposium: Challenges in African Hydrology and Water Resources, IAHS, Netherlands, 155-160.

[14] Gibson, J.J., Edwards, T.W.D., Birks, S.J., St Amour, N.A., Buhay, W.M., Mceachern, P. and Peters, D.L. (2005) Progress in Isotope Tracer Hydrology in Canada. Hydrological Processes, 19, 303-327. http://dx.doi.org/10.1002/hyp.5766

[15] Clark, I.D. and Fritz, P. (1997) Environmental Isotopes in Hydrogeology. CRC Press, Boca Raton, 185.

[16] Chowdhury, A., Jha, M. and Chowdary, V.M. (2010) Delineation of Groundwater Recharge Zones and Identification of Artificial Recharge Sites in West Medinipur District, West Bengal, Using RS, GIS and MCDM Techniques. Environmental Earth Sciences, 59, 1209-1222. http://dx.doi.org/10.1007/s12665-009-0110-9

[17] Mondaln. C. and Singhv. S. (2004) A New Approach to Delineate the Groundwater Recharge Zone in Hard Rock Terrain. Current Science, 87, 658-662. 
[18] Hunt, R.J., Steuer, J.J., Mansor, M.T. and Bullen, T.D. (2001) Delineating a Recharge Area for a Spring Using Numerical Modeling, Monte Carlo Techniques, and Geochemical Investigation. Ground Water, 39, 702-712. http://dx.doi.org/10.1111/j.1745-6584.2001.tb02360.x

[19] Girmay, E., Ayenew, T., Kebede, S., Alene, M., Wohnlich, S. and Wisotzky, F. (2015) Conceptual Groundwater Flow Model of the Mekelle Paleozoic-Mesozoic Sedimentary Outlier and Surroundings (Northern Ethiopia) Using Environmental Isotopes and Dissolved Ions. Hydrogeology Journal, 23, 649-672.

[20] Datta, P.S. and Tyagi, S.K. (2009) Delineation of Potential Groundwater Recharge and Productive Aquifer Zones in Delhi Area Based on ${ }^{18} \mathrm{O}$ Signatures and GPS. Journal of Agricultural Physics, 9, 33-37.

[21] Praamsma, T., Novakowski, K., Kyser, K. and Hall, K. (2009) Using Stable Isotopes and Hydraulic Head Data to Investigate Groundwater Recharge and Discharge in a Fractured Rock Aquifer. Journal of Hydrology, 366, 35-45. http://dx.doi.org/10.1016/j.jhydrol.2008.12.011

[22] Perleros, V., Papamastorakis, D., Kritsotakis, M., Drakopoulou, E. and Panagopoulos, A. (2004) Groundwater Potential of the Island of Crete. Problems and Perspectives. Bulletin of the Geological Society of Greece, 36, 2048-2056.

[23] Araguas-Araguas, L., Froehlich, K. and Rozanski, K. (2000) Deuterium and Oxygen-18 Isotope Composition of Precipitation and Atmospheric Moisture. Hydrological Processes, 14, 1341-1355. http://dx.doi.org/10.1002/1099-1085(20000615)14:8<1341::AID-HYP983>3.0.CO;2-Z

[24] Press, W.H., Teukolsky, S.A., Vetterling, W.T. and Flannery, B.P. (2002) Numerical Recipes in C ${ }^{+}$. Chapter 14: Statistical Description of Data. Cambridge University Press, Cambridge.

[25] Hendrya, M.J. (1988) Do Isotopes Have a Place in Ground-Water Studies? Groundwater, 26, 410-415. http://dx.doi.org/10.1111/j.1745-6584.1988.tb00406.x 